\title{
Nutritional Evaluation and Chemical Analysis of Two Commercial Infant Foods in South-Western, Nigeria
}

\author{
Ibironke Samson Ishola, Ige Meshach Morakinyo \\ Department of Food Science and Technology, Obafemi Awolowo University, Ile-Ife, Nigeria
}

Email address:

isolaibironke@yahoo.com (Ibironke, S. I.), isolaibironke@gmail.com (Ibironke, S. I.)

To cite this article:

Ibironke Samson Ishola, Ige Meshach Morakinyo. Nutritional Evaluation and Chemical Analysis of Two Commercial Infant Foods in SouthWestern, Nigeria. International Journal of Nutrition and Food Sciences. Vol. 4, No. 5, 2015, pp. 590-593. doi: 10.11648/j.ijnfs.20150405.22

\begin{abstract}
The purpose of this study is to nutritionally assess and compare two selected formulas such as maize-legume based infant formula (MLBIF) and maize-milk based infant formula (MMBIF) Dietary samples consisted of (1) Basal, diet (2) maize-legume based infant formula (MLBIF) (3) The maize-milk based infant formula (MMBIF) complementary diets. They were both obtained at a local supermarket, Ile-Ife, South-West, Nigeria. Thirty (30) albino rats were then reweighed and grouped into three groups of ten each. The result showed that the growth rate, (non protein diet) declined from $35.962-30.910$, two formulas (protein diet) increased from, 35.636 to 82.521 and 35.90 to 79.570 diets 12 2, 3, respectively. Protein efficiency ratio (PER) for diets1 2, 3 were nil, 3.12 and 2.90 respectively. Net protein ratio (NPR) were nil 2.78 and 2.56 for diets1 2, and 3 , respectively. Protein retention efficiency $(\mathrm{PRE}=$ NPRX16) were nil, 44.50 and 41.07 respectively. The average nitrogen retained in various organs of experimental animals, such as liver, kidney and muscle of the diets 1, 2, 3 were 33.52, 43.60, $45.80 ; 56.76,50.63,58.70 ; 55.22,51.38$ and 56.08 respectively. The was MLBIF found superior compared to maize based infant formula (MMBIF) in terms of growth rate, protein efficiency ratio (PER), net protein ratio (NPR), protein retention efficiency (PRE) and ensure optimum nitrogen content in the liver, kidney and tissues. These findings showed that the MLBIF infant formula is cheaper in the market than infant MMBIF formula, and could be affordable by less privileged and may be used in alternative, where infant reacts to milk based dietary.
\end{abstract}

Keywords: Infant Formulas MMBIF, MLBIF, Experimental Animals

\section{Introduction}

Adequate nutrition during infancy and early childhood is fundamental to the developmental. The birth period from birth to 2years of age is most critical for the promotion of optimal health, growth and psychological development (FAO/WHO1991, 1998). The health implications of poor nutrition during the first 2 years of life include multifarious illness, impaired mental and physical development and cases death. Intervention such as diet-based strategies are reported to be one of the most promising approach for a sustainable control of micronutrient deficiencies among the under five children (FAO/WHO1991, 1998). Dietary supplementation of varied foods which through home gardening has been suggested to be succour to Protein-energy malnutrition in major public health problem among children throughout the developing world. Breast milk is regarded as the optimal source of nutrient, suitable and balance diet for the infants but where there is shortage of breast milk, Iron-fortified infant formula, could be applied as an alternative for the infant's first year of life (CNAP, 1992).

There were varieties of infant formulae that are manufactured for healthy, full-term infants who are not breastfed or partially breastfed (FDA 2005): In Nigeria, children especially those from low class are mainly weaned on cheap starchy foods which are readily available not hygienically produced, In addition, report showed that such as poor nutrition education and cost of imported commercial infant foods and animal proteins result in protein energy malnutrition problem prevalent in the developing countries (Dewey \& Brown 2003): The development and introduction of complementary foods or infant formulas should follow both generally acceptable by WHO guidelines (WHO, 2002). Hence, the objective of this study was to evaluate and compare two selected infant formulas, in the local supermarket, one which is maize-legume based infant formula (MLBIF) and the other maize-milk based infant formula (MMBIF). 


\section{Materials and Methods}

The materials for the formulations

Maize grains, MLBIF $1 \mathrm{~kg}$ cost N1000 equivalent to $\$ 4$ and MMBIF $0.9 \mathrm{~kg}$ cost N1250, equivalent to $\$ 5$, both were products of Nestle PLC, Nigeria. They were purchased from a local supermarket in Ile-Ife, South-West, Nigeria.

Table 1. The nutrient composition of basal diets.

\begin{tabular}{ll}
\hline Nutrient & $\mathbf{g} / \mathbf{k g}$ \\
\hline Protein & - \\
Corn flour & 800 \\
Sugar & 60 \\
Vegetable oil & 100 \\
Vitamin mix & 10 \\
Salt mix & 30 \\
\hline
\end{tabular}

Table 2 shows the nutrient compositions of the basal diet such as protein, sugar, vegetable oil, vitamin mix, salt mix, cod liver oil and calorie. This was used to mix other diets to attain desire caloric value of the formulated diets, because it was regarded as non- protein dietary. This corresponds to the formula previously discussed (Fashakin, et al 1986)

Calculations for regulating MMBIF and MLBIF to $10 \%$ level of protein

MMBIF was regulated to $10 \%$ level of protein with basal diet, in order to obtain an isonitrogenous calories.

To reduce $15 \%$ protein content of MMBIF mixture to $10 \%$ protein content, the mixture was simply diluted with the use of basal diet. The calculation is as shown below.

$$
\frac{15}{100} \times b=\frac{10}{100} \times 100 g
$$

$\mathrm{a}=66.66 \mathrm{~g}$

$\mathrm{b}=100 \mathrm{~g}-66.66 \mathrm{~g}=33.34 \mathrm{~g}$

$\mathrm{a}=$ weight of required MMBIF for the new mixture

$\mathrm{b}=$ weight of basal diet required to achieve $10 \%$ protein

content in the new mixture (Ibironke et al 2012, 2014abcd)

MLBIF was regulated to $10 \%$ level of protein with basal diet, in order to obtain isonitrogenous calories.

To reduce $16 \%$ protein content of MLBIF mixture to $10 \%$ protein content, the mixture was simply diluted with the use of basal diet

$$
\frac{16}{100} X \mathrm{c}=\frac{10}{100} \times 100 \mathrm{~g}
$$

$\mathrm{c}=62.5 \mathrm{~g}$

$\mathrm{d}=100 \mathrm{~g}-62.5 \mathrm{~g}=37.5 \mathrm{~g}$

$\mathrm{c}=$ weight of MLBIF required for the new mixture

$\mathrm{d}=$ weight of basal diet required to achieve $10 \%$ protein content in the new mixture (Ibironke et al 2012, 2014abcd)

\subsection{Animal Experiment}

Thirty (30) weaning albino rats were obtained from College of Heath Science breeding centre, Obafemi Awolowo University, Ile-Ife, Nigeria. The rats were weighed and randomly allocated to metabolic cages. The weight and age ranged between 28.60 to $44.05 \mathrm{~g}$ and 3 to 4 weeks respectively. The rats were accommodated in metabolic cages fixed with a cup and a small plastic bottle to supply food and water ad libitum (Ibironke et al 2012, 2014abcd).

The animals were acclimatised to the new environment by feeding them on normal diets for seven days. The animals were then reweighed and grouped into three groups of ten each, in such a way that the weights were similar. For example groups, 1, 2, and 3 had the weights $35.96 \mathrm{~g}, 35.90 \mathrm{~g}$ and $35.64 \mathrm{~g}$ respectively. At zero day, one group (control) was set aside for sacrifice to remove, the liver, and kidney and also the tissue of the hind leg were taken, weighed and frozen for chemical analysis (Ibironke et al 2012, 2014abcd). The other groups (1-3) were placed on experimental diets for 28 days. They were given a weighed quantity of each experimental diet, in a feeding dish and water was supplied ad libitum via a plastic bottle attached to the cage. Daily consumption of samples was carefully recorded and the weights were noted. Weight gain/loss of the experimental animals was taken every three days. At the end of the experiment, which is after twenty-eight days, the experimental animals were sacrificed in similar way as control. Organs including kidney, liver and muscle of the hind leg were obtained, weighed, stored and frozen at $-400 \mathrm{C}$ for nitrogen determination (Ibironke et al 2012, 2014abcd).

\subsection{Chemical Analysis}

Protein (nitrogen $x$ 6.25), moisture, fat, crude fibre carbohydrate, and vitamins of the ingredients and formulated diets were determined according to AOAC methodology. Energy value was determined using Combustion calorimeter, model e2K (AOAC 2000).

\section{Results and Discussion}

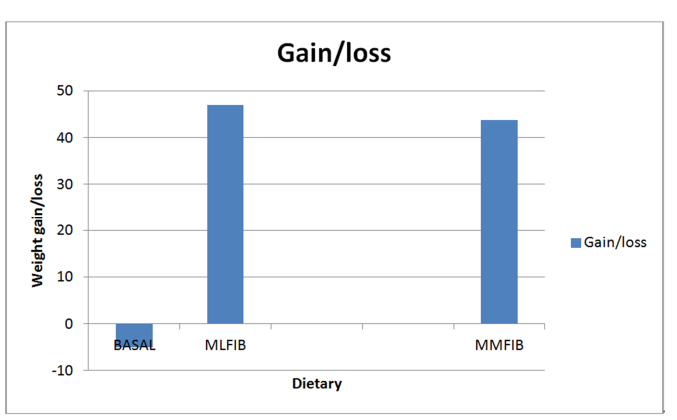

Figure 1. Weight gain/loss of the experimental animal during 28 days.

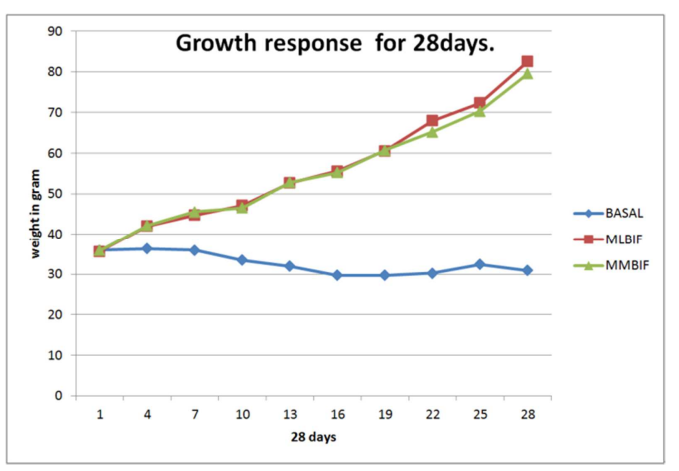

Figure 2. Growth response of the experimental animals during 28 days. 
Figures 1 and 2 showed the growth rate and response to dietary intake of the experimental animals during 28 days. The growth response was slightly higher in, MLBIF (diet 2) cereal based diet, than milk-based diet, MMBIF (diet 3), and basal diet, non protein dietary (diet 1) respectively. Diets 2 promoted growth more than diet 3 , final weight values was higher than initial values which indicated that the diet 2 may have better performance, complete amino acid profile when compare to other formulated diets. Although, both two formulas were manufactured by nestle plc diets 2 (cereal- based diet) and diet 3 (milk -based diet). The cereal based diet showed more efficacy than milk based diet in terms of growth response: nitrogen retained and weight gained. Researchers have demonstrated adequate nutrients intake. However, diet 1, could not support growth and found to decrease the weight of the animals in group 1. This may be due to the fact that the diet lacked adequate nutrient such as protein, and may be deficient in essential amino acids, that should support growth. This 1diet hence was not nutritionally adequate to enhance growth (Ibironke et al 2012, 2014abcd).

Table 2. Proximate composition (\%) of the ingredients.

\begin{tabular}{llllllllll}
\hline Dietary & Protein\% & Moisture\% & Fat\% & Ash\% & Crude\% fibre & CHO\% & Caloric value (Kcal) & Vitamin Cmg/100g & Vitamin B1 mg/100g \\
\hline MLBIF & 16 & 2.50 & 9.0 & 2.60 & 4.06 & 64.20 & 398 & 50 & 0.8 \\
MMBIF & 15 & 2.50 & 9.0 & 2.60 & 2.95 & 67.45 & 413 & 17 & 17 \\
\hline
\end{tabular}

Table 2 shows the chemical analysis (\%) of the ingredients which including protein, moisture, fat, ash, crude fibre carbohydrates, vitamin C mg/100g, Vitamin B1 mg/100g and caloric values. The ingredients were nutritionally adequate to formulate a complementary food and meet the estimated daily nutrient requirements for complementary foods (Butte, 1996, Ibironke et al 2012, 2014abcd).

Table 3. Average food consumption over the 28 days of the experimental period.

\begin{tabular}{lllllll}
\hline \multirow{2}{*}{ Diet } & \multicolumn{6}{l}{ Time in Days } \\
\cline { 2 - 7 } & $\mathbf{5}$ & $\mathbf{1 0}$ & $\mathbf{1 5}$ & $\mathbf{2 0}$ & $\mathbf{2 5}$ & $\mathbf{2 8}$ \\
\hline Basal & 21.77 & 46.24 & 65.05 & 84.26 & 98.88 & 113.63 \\
MLBIF & 34.68 & 61.82 & 100.04 & 121.76 & 130.65 & 150.90 \\
MMBIF & 38.52 & 79.20 & 105.47 & 122.92 & 136.65 & 150.97 \\
\hline
\end{tabular}

Table 3 highlights the average food consumption over the 28 days of the experimental period, MLBIF, and MMBIF basal diets.

Table 4. The average nitrogen retained in various tissues of experimental animals.

\begin{tabular}{llll}
\hline Dietary & Liver(mg/g) & Kidney(mg/g) & Muscle(mg/g) \\
\hline Basal & 33.52 & 43.60 & 45.80 \\
MLBIF & 56.76 & 50.63 & 58.70 \\
MMBIF & 55.22 & 51.38 & 56.08 \\
\hline
\end{tabular}

Table 4 outlines the average nitrogen retained in the various organs of the animal experimental animals including the liver, kidney and tissue. The nitrogen is general reflection of dietary nitrogen level. The average nitrogen retained in diets 2, 3, organs of experimental animals were similar but the highest retention of nitrogen was found in experimental animals that fed on diet 2 compared with the both diet 1 and diet 3 , while the average nitrogen retained in diet 1 (non protein dietary) organs of the experimental animals was lowest compared with diets 2 (cereal- based diet), and diet 3 (milk- based diet) as shown in table 5. It could be inferred that diets 2 , and 3 , have enough nutrients which has been be retained by the experimental animals, and this may be due to the fact that amino acid profile of all infant formulae dietary are complete and that the diets can liberate more nitrogen that is sufficient to supply to the body organ, this is in agreement with previous findings (Rivera, and Lutter2 001, Lutter, 2000, Ibironke et al 2012, 2014abcd).

Table 5. Average weight in grams of various organs of the experimental animal.

\begin{tabular}{llll}
\hline Dietary & Liver(g) & Kidney(g) & Muscle(g) \\
\hline Basal & 3.206 & 3.204 & 3.423 \\
MLBIF & 4.087 & 4.655 & 3.532 \\
MMBIF & 4.086 & 4.563 & 3.530 \\
\hline
\end{tabular}

Table 6. Biological values of the formula.

\begin{tabular}{llll}
\hline Dietary & PER & NPR & PRE=NPRX16 \\
\hline Basal & - & - & - \\
MLBIF & 3.12 & 2.78 & 44.50 \\
MMBIF & 2.90 & 2.56 & 41.07 \\
\hline
\end{tabular}

Table 6 highlighted the Biological values of the formulae, diets 2 and 3 MLBIF slightly higher compared to MMBIF in terms of PER, NPR and PRE. Basal diet has no biological value because it contains no protein, and it is deficient in amino acid, hence could not support growth (Lutter, 2000, Ibironke et al 2012, 2014abcd).

\section{Conclusion}

The MLBIF compared was found to be superior to MMBIF in terms of growth rate, protein efficiency ratio (PER), net protein ratio (NPR), and protein retention efficiency (PRE) as well as optimum nitrogen content in the liver, kidney and tissues. These findings showed that the infant MLBIF formula which is cheaper in the market than MMBIF infant formula, could be affordable by the less privileged and may be used as an alternative, infant weaning diet to milk based dietary to combat protein energy malnutrition (PEM).

\section{References}

[1] AOAC (2000): Official Methods of Analysis of the Association of Official: Analytical Chemists, 17th Edition, Washington Dc. 
[2] Butte, NF (1996): Energy requirements of infants. Eur. J. Clin. Nutr. 50(1):S24-S36.

[3] CNAP (1992) Committee on Nutrition, American Academy of Pediatrics. The use of whole cow's milk in infancy. Pediatrics: 89(6):1105-1109.

[4] Dewey, KG. \& Brown, KH (2003): Update on technical issues concerning complementary feeding of young children in developing countries and implications for intervention programs. Food Nutr. Bull. 24(1):5-28.

[5] FAO/WHO (1998) Preparation and use of Food-Based Dietary Guidelines. Report of a Joint. FAO/WHO Consultation. WHO Technical Report series 880. Geneva.

[6] FAO/WHO (1991) Codex standard for processed cereal-based foods (including guidelines on formulated supplementary foods for older infants and young children: World Health Organization Geneva, Switzerland.

[7] Fashakin, J. Awoyefa, M. Furst P (1986): The application of protein concentrates from locally legumes in the development of weaning foods: ZErnahrungswiss: 25: 220-227.

[8] FDA (2005): Food and Drug Administration Quick Information: Feeding Your Baby with Breast Milk or Formula. (accessed on August 26, 2011). Available at: http://www.fda.gov/opacom/lowlit/ feedbby_brochure.pdf.

[9] Ibironke Samson Ishola, Mojisola Aderonke Adeniyi, Joseph Bandele Fashakin, (2014) a: "Nutritional evaluation of complementary food formulated from fermented maize, pigeon pea and soybeans", Nutrition \& Food Science, $44(5) 464-470$.
[10] Ibironke Samson Ishola, (2014) b: Formulation of Infant Weaning Foods from Vegetable Proteins and Cereal. American Journal of Food Technology, 9(2) 104-110.

[11] Ibironke Samson Ishola, Joseph Bandele Fashakin, Badmus OA, (2012): Nutritional Evaluation of Complementary Food Developed from Plant and Animal Protein Sources: Emerald, Nutrition \& Food Science: 42 (2) 111-120.

[12] Ibironke, S Ishola, Joseph B Fashakin, and Morakinyo M IGE (2014) c: Nutritional Quality of Animal Polypeptide (Crayfish) Formulated Into Complementary Foods." American Journal of Food and Nutrition: 2 (3) 39-42.

[13] Ibironke, Samson Ishola, Joseph Bandele FASHAKIN, Morakinyo Meshach IGE, Victor Abiodun IKUJENLOLA (2014) d: Formulation of Complementary Foods Developed from Plants Polypeptide (Parkia Biglobosa), Soy Bean and Maize: American Journal of Nutrition and Food Science: 1(4):72-77.

[14] Lutter, C. (2000): Processed complementary foods: summary of nutritional characteristics, methods of production and distribution, and costs. Food Nutr. Bull. 21(1):95-100.

[15] Rivera, J. \& Lutter, C: (2001): The potential role of processed complementary foods in Latin America. In Nutrition and Growth. Martorell, M. Haschke, R. eds. Nestlé Nutrition Workshop Series Pediatric. Program 47 Lippincott Williams and Wilkins Philadelphia, PA.

[16] World Health Organization (2002): Global Strategy for Infant and Young Child Feeding. Doc A55/15 World Health Organization Geneva, Switzerland. 